\title{
Vitamin D deficiency in pediatric clinical practice
}

\author{
Gustavo Cediel, Ph.D. ${ }^{a}$, Johanna Pacheco-Acosta, M.D. ${ }^{b}$ and Carlos Castillo-Durán, M.D. ${ }^{+b}$
}

\begin{abstract}
Vitamin D research suggests it has a role in disorders other than bone metabolism.

Objective: To update the information on vitamin Ddeficiency(VDD) in pediatric clinical disorders. Methods: Search in virtual libraries, giving priority to clinical and longitudinal studies and meta-analyses on VDD in the pediatric age group published in the past 20 years. The terms "vitamin D deficiency", "children and adolescents" (both in Spanish and English) were used as search descriptors.

Results: In the pediatric population, VDD is associated with different clinical diseases, such as bone alterations, insulin resistance, metabolic syndrome, respiratory tract infections, asthma, and autoimmune diseases. Besides, it is associated with prematurity, obesity, malabsorption, use of anticonvulsant agents, and lifestyle characteristics, such as clothing, extreme latitudes, low consumption, and little sun exposure.

Conclusions: According to the evidence, VDD is highly prevalent in several disorders and diseases in the pediatric age group. The recommendation is to prevent VDD in risk conditions and to maintain 25(OH)D serum levels $>75 \mathrm{nmol} / \mathrm{L}$. Key words: vitamin $D$, deficiency, review, child.
\end{abstract}

http: / / dx.doi.org/10.5546/aap.2018.eng.e75

To cite: Cediel G, Pacheco-Acosta J, Castillo-Durán C. Vitamin D deficiency in pediatric clinical practice. Arch Argent Pediatr 2018;116(1):e75-e81.

a. Institute of

Nutrition and Food

Technology (Instituto

de Nutrición y

Tecnología de los

Alimentos, INTA),

Universidad de Chile.

b. Department of

Pediatrics, Central

Campus of the

School of Medicine,

Universidad de Chile.

E-mail address:

Gustavo Cediel, Ph.D.: gcediel@inta.uchile.cl

Funding:

None.

Conflict of interest:

None.

Received: 2-3-2017

Accepted: 7-6-2017

\section{INTRODUCTION}

Vitamin D (VD) research has played an increasingly growing role because of the following: 1) VD receptor characterization (nuclear and cytosolic) and the enzymatic machinery that metabolizes VD in multiple tissues (e.g., adipose tissue, muscle, and pancreas); ${ }^{1}$ 2 ) the role related to the regulation of more than 200 genes, ${ }^{2}$ and 3) the risk associated with the suboptimal range of 25-hydroxyvitamin D [25(OH)D] and the presence of multiple diseases. ${ }^{3}$ As a result, in the field of pediatrics, it is very important to discuss VD's nonbone roles and consider the necessary measures to prevent VD deficiency (VDD).
The objective of this review was to update the information on VDD in some clinical disorders occurring in the pediatric age group. The search was done using the online libraries Pubmed and Scielo, and bibliographic references of other reviews. The terms "vitamin D deficiency", "children and adolescents" (both in Spanish and English) were used as search descriptors. Inclusion criteria were articles published in the past 20 years, giving priority to randomized controlled trials, case-control studies, and meta-analyses.

\section{Vitamin D deficiency in children and adolescents}

In the past decade, VDD rickets has re-emerged, ${ }^{4}$ mainly in association with a low consumption of VD food sources and little exposure to the sun (winter, clothing and / or excessive sunscreen use).5,6 Available studies conducted in the pediatric population show that $25(\mathrm{OH}) \mathrm{D}$ serum levels range between $24.5 \mathrm{nmol} / \mathrm{L}$ (Ushuaia, Argentina) and $116 \mathrm{nmol} / \mathrm{L}$ (Tehran, Iran). ${ }^{7}$ The size of this problem in children and adolescents in Latin America is unknown; only Mexico has representative data at a national level that show a $54 \%$ and $28 \%$ prevalence of VD deficiency and insufficiency in preschoolers and school children, respectively. ${ }^{8}$ Argentina has representative data available for the Patagonia region in children aged 6-23 months, who had a mean $25(\mathrm{OH})$ D serum level of $67.5 \mathrm{nmol} / \mathrm{L}(95 \%$ confidence interval [CI]: 65.3-69.8), with extreme values ranging from 10.5 to $177.5 \mathrm{nmol} / \mathrm{L}$. As observed, values for the provinces assessed in the months closer to winter (Chubut, Neuquén, and Santa Cruz) are significantly lower than in those 
assessed in November and December (Río Negro, Tierra del Fuego, and La Pampa). ${ }^{9}$ Some countries have reported a VDD prevalence in children using non-representative samples, e.g., Colombia: 10-12\% (< $50 \mathrm{nmol} / \mathrm{L})$, Brazil: $9 \%(<50 \mathrm{nmol} / \mathrm{L})^{8}$ and, more recently, Chile: $64 \%(<50 \mathrm{nmol} / \mathrm{L})$ among preschoolers from southern regions (> 45 $\left.5^{\circ} 35^{\prime} \mathrm{S}\right) .{ }^{10}$ This evidence suggests a high prevalence of VD deficiency and insufficiency in children and adolescents, especially during the winter and at extreme latitudes.

\section{Clinical characteristics of vitamin D deficiency in children and adolescents}

Multiple studies have established an association between low 25(OH)D serum levels and the presence of non-bone diseases in children. ${ }^{3}$ Below we describe the evidence available on the association between different clinical diseases and VDD in the pediatric age group (Table 1).

Prematurity and VDD: The third trimester of gestation is the most relevant period in terms of bone mineral mass gain and, therefore, in this period there is an increase in bone alterations caused by VD deficiency. ${ }^{11}$ A recent study assessed 100 children with a gestational age (GA) between 23 and 27 weeks and a mean weight of $770 \mathrm{~g}$ who received different VD doses. At 28 days of life, VDD was observed in $41 \%$ of infants from the placebo group, in 16\% from the group dosed with 200 IU daily, and in 0\% from the group dosed with $800 \mathrm{IU}$ daily. ${ }^{12}$ This is consistent with the recommendations made by the European Society for Paediatric Gastroenterology, Hepatology and Nutrition (ESPGHAN) to administer VD at 800-1000 IU / day estimated based on feeding and oral supplementation. ${ }^{13}$

Obesity and VDD: The evidence obtained from prepubertal children shows a reverse association between 25(OH)D serum levels and adiposity indicators, ${ }^{14,15}$ and this is consistent with the hypothesis of VD sequestration in adipose tissue because of its lipid-soluble nature. ${ }^{16}$ These findings are also consistent with a recent study that demonstrated that excess weight in children had an effect on VD supplementation and that these children achieved a lower $25(\mathrm{OH})$ D increase; therefore, children with excess weight may require higher VD doses than normal weight children to achieve the same $25(\mathrm{OH}) \mathrm{D}$ levels. ${ }^{17}$ Considering the effect of adiposity on VD bioavailability, countries from central Europe have issued specific recommendations for obese children and adolescents: supplementation with 1200-2000 IU/day (30-50 $\mu \mathrm{g} /$ day) depending on obesity severity during the fall and winter; however, it is recommended all-year round if skin synthesis is not enough during the summer. ${ }^{18}$

The evidence suggests that the active form of VD [1,25(OH)2D] regulates gene transcription in adipogenesis, inflammation, and insulin

TABLE 1. Recommendations for vitamin D supplementation in different diseases in the pediatric age group

\begin{tabular}{ll}
\hline Disease & Recommendation \\
\hline Obesity & Administer VD3 at 1200-2000 IU / day. ${ }^{18}$ \\
Insulin resistance & Administer VD3 at $4000 \mathrm{IU} /$ day for 6 months to obese children and adolescents with VDD. ${ }^{20}$ \\
Metabolic syndrome & Studies are still required to clarify adequate VD dosing and duration and establish its effects. \\
Type 1 diabetes & Administer VD3 at $2000 \mathrm{IU} /$ day. ${ }^{38}$ \\
Cystic fibrosis & - Children $<1$ year old: VD3 at $400-800 \mathrm{IU} /$ day; if $25(\mathrm{OH}) \mathrm{D}<75 \mathrm{nmol} / \mathrm{L}$, increase to a dose \\
& between $800 \mathrm{IU}$ and up to $2000 \mathrm{IU}$. \\
& - Children $1-10$ years old: VD3 at $800-1000 \mathrm{IU} /$ day, up to $4000 \mathrm{IU} /$ day if $25(\mathrm{OH}) \mathrm{D}<75 \mathrm{nmol} / \mathrm{L}$. \\
& - Children $>10$ years old: VD3 at $800-2000 \mathrm{IU} /$ day, up to $10000 \mathrm{IU} /$ day if $25(\mathrm{OH}) \mathrm{D}<75 \mathrm{nmol} / \mathrm{L}$, \\
& until reaching values from 75 to $150 \mathrm{nmol} / \mathrm{L} .{ }^{37}$ \\
Celiac disease & Gluten-free diet. Administer VD3 at $400-600 \mathrm{IU} /$ day and adhere to calcium requirements. ${ }^{40}$ \\
Respiratory tract infections & Studies are still required to clarify adequate VD dosing and duration in relation to beneficial \\
& effects. \\
Asthma & There is no strong evidence to support VD3 supplementation at 500-1200 IU / day. ${ }^{56}$ \\
Neurological diseases & Administer VD3 at 800-1000 IU / day. ${ }^{41}$ \\
\hline
\end{tabular}

VD: vitamin D. 
resistance in the adipose tissue of obese patients. ${ }^{19}$ In addition, in muscle and pancreas, $1,25(\mathrm{OH}) 2 \mathrm{D}$ may improve insulin sensitivity through the regulation of calcium flow in these tissues, by controlling insulin secretion in pancreatic beta cells and increasing insulin receptor expression in peripheral tissues. ${ }^{1}$ Recent results obtained from prepubertal children show a mild reverse association between 25(OH)D serum levels and insulin resistance indicators, even after adjusting them for adiposity. The $75 \mathrm{nmol} / \mathrm{L}$ cut-off point for $25(\mathrm{OH}) \mathrm{D}$ is the best predictor for these conditions. ${ }^{14} \mathrm{~A}$ controlled clinical study conducted in obese children and adolescents aged 9-19 years found a significant reduction in the homeostatic model assessment of insulin resistance (HOMA-IR) in the active group versus the placebo group following the administration of 4000 IU / day of VD3 for 6 months (active group: -1.36 versus placebo group: +1.2$).{ }^{20} \mathrm{In}$ addition, knowledge on the active form of VD as a hormone with insulin-like actions in children started almost 20 years ago, and it has been observed that VD supplementation reduces the risk for type 1 diabetes. ${ }^{21-25}$ The correlation to type 1 diabetes may be attributed to the systemic anti-inflammatory actions of VD as an immunomodulator, acting on dendritic cells, $\mathrm{T}$ cell differentiation, and the interference in cytokine generation and action. ${ }^{26}$

Metabolic syndrome and VDD: A cross-sectional analysis of the 2001-2004 National Health and Nutrition Examination Survey (United States) found that low VD levels in adolescents were strongly associated with metabolic syndrome, regardless of adiposity. ${ }^{27}$ Another study conducted in Argentine indigenous schoolchildren (a group at a higher risk for dyslipidemia) showed a reduction in low density lipoproteins cholesterol (LDL-C) following VD supplementation (beta $=-0.41, p<0.01){ }^{28-30}$ Although the biological mechanisms involved in these associations have not been completely elucidated yet, the evidence suggests that VD acts as a cardiovascular and renal protective factor by suppressing the renin-angiotensin-aldosterone system, which inhibits vascular calcification and plaque formation, and also has anti-inflammatory and immunomodulatory actions. ${ }^{31-33}$

Intestinal malabsorption syndromes and VDD: VDD prevalence in patients with intestinal malabsorption syndromes, including cystic fibrosis $(\mathrm{CF})$, celiac disease $(\mathrm{CD})$, short bowel syndrome, and inflammatory bowel disease, is higher than in the general population. VD decrease in these patients is the result of several factors, such as a reduced absorption of lipidsoluble vitamins, a greater inflammationmediated extrarenal expression of CYP27B1, and hyperparathyroidism secondary to hypocalcemia in some patients; this leads to a greater $25(\mathrm{OH}) \mathrm{D}$ conversion into $1,25(\mathrm{OH}) 2 \mathrm{D}$ and, therefore, lower 25(OH)D levels. ${ }^{34}$

Cystic fibrosis and VDD: The prevalence of an inadequate VD status in patients with CF may be as high as $95 \% .{ }^{35}$ Ninety percent of the CF population have pancreatic insufficiency, which causes malabsorption of fat and, therefore, lipid-soluble vitamins, including VD. However, VDD has also been observed in up to $50 \%$ of patients with $\mathrm{CF}$ who have a normal pancreatic function. ${ }^{36}$ In recent years, outcomes other than bone health in relation to VD have been assessed in children with CF; in this regard, recent studies have established an association between $25(\mathrm{OH})$ $\mathrm{D}$ levels and pulmonary function and bacterial colonization by S. aureus and Pseudomonas $s p .^{36}$ At present, the United States Cystic Fibrosis Foundation recommends measuring $25(\mathrm{OH})$ $D$ every three months and adjusting the dose to achieve sufficient levels of $25(\mathrm{OH}) \mathrm{D}$ $(>75 \mathrm{nmol} / \mathrm{L}){ }^{37}$

Celiac disease and VDD: VD and calcium levels are reduced in most patients with untreated CD. This is because of several reasons: malabsorption caused by epithelial-intestinal damage, milk restriction due to the associated lactose intolerance and/or reduced calcium binding protein expression, which is regulated by VD. Also, studies have not found a relationship between healthy people and $\mathrm{CD}$ patients in terms of VD receptor polymorphisms. Tanpowpong and Camargo described the hypothesis that VDD led to a deregulated immune response, especially a disruption of the intestinal mucosal integrity in the antigen presentation (gluten) and microbial antigens (viral gastrointestinal infections), which promoted an unfavorable microbial environment among individuals who are genetically predisposed to developing CD. Thus, VDD during a critical period of life such as the first year may increase the risk of developing $\mathrm{CD}$ in the future. ${ }^{39}$ The objective is to maintain $25(\mathrm{OH}) \mathrm{D}$ levels $>75 \mathrm{nmol} / \mathrm{L}$ and, to this end, the main treatment is a strict gluten-free diet, which has shown improvements in VD and calcium serum levels as well as in bone mineral density in children and adolescents. ${ }^{40}$ 
Anticonvulsant agents and VDD: VDD prevalence in children with epilepsy receiving anticonvulsant agents is above $50 \% .{ }^{41}$ Phenytoin, phenobarbital, and carbamazepine interfere with VD metabolism. These drugs act at the hepatic microsomal level by inducing the activity of cytochrome P450 hydroxylase enzymes, thus leading to an accelerated VD and metabolite catabolism and a reduced activity; however, such enzyme inducers are only one of the factors associated with VDD. Other associated factors include polypharmacy, anticonvulsant therapy duration (79\% of VD deficiency and insufficiency cases have been observed with more than 2 years of treatment), prostration, nasogastric or gastrostomy tube feeding. ${ }^{41}$ As a result, the recommendation is to administer VD supplementation at a dose of 800-1000 IU / day to children with neurological disease. ${ }^{41}$

Respiratory tract infections and VDD: During the first year of life, the risk for respiratory syncytial virus (RSV) bronchiolitis is higher if VD cord blood levels are $<50 \mathrm{nmol} / \mathrm{L} .^{42}$ The studies conducted in Germany by Łuczyńska et al. ${ }^{43}$ reported that the risk for acute lower respiratory tract infections (ALRTIs) practically doubled in infants with VD cord blood levels $<25 \mathrm{nmol} / \mathrm{L}$. In addition, there is a seeming relationship between VDD and a more severe RSV bronchiolitis. Such reduction in the response against RSV may be associated with the Fok-I polymorphism of VD receptor and a VD-mediated lower inflammatory response of airway epithelial cells. ${ }^{44}$ In addition, VD has been described as being effective to reduce the risk for influenza and to achieve an adequate vaccine response because it activates $T$ cells. ${ }^{45,46}$ Our search results showed no evidence that would support a beneficial effect of VD supplementation to prevent acute respiratory infections, reduce mortality or the rate of hospitalizations due to respiratory infections. ${ }^{47}$

Asthma and VDD: Several studies have established an association between VDD and asthma severity. Einisman et al. ${ }^{48}$ found no differences in 25(OH)D levels between healthy and asthmatic children; however, the group of children with asthma showed a difference in the levels of sufficiency of $25(\mathrm{OH}) \mathrm{D}$, which were higher among asthmatics according to the Global Initiative for Asthma (GINA) treatment step 4. Also in this group, the Fok-I C allele of the VD receptor was present in all children, unlike the other children with asthma. A recent meta-analysis assessed studies on VD supplementation (VD3 doses ranging from 500 to $1200 \mathrm{IU}$ / day) and showed a significant reduction in the risk for asthma exacerbation $(\mathrm{RR}=0.28,95 \% \mathrm{CI}: 0.12-0.64) .{ }^{49}$ There is still no consensus on the doses and duration of VD in children with asthma; however, most of the evidence is in favor of using VD3 at a dose of 500$1200 \mathrm{IU} /$ day together with the standard asthma treatment.

Other clinical disorders associated with VDD: Recent studies have established an association between VDD and other clinical disorders. For example, it is worth noting the association between VDD and menarche, which started 9 months earlier among girls with VDD compared to those with normal VD levels in Bogotá, Colombia. ${ }^{50} \mathrm{~A}$ reverse association has been reported between 25(OH)D levels and systolic blood pressure in adolescents. ${ }^{51}$ There are other studies that have been conducted in recent years and showed a potential association with some forms of cancer, both in adults and children. ${ }^{2}$ Future studies will demonstrate if VDD management prevents any of these diseases.

\section{Vitamin D deficiency prevention in children and adolescents}

According to the evidence, exposure to ultraviolet rays in a small portion of the dorsal area of the body rapidly increases $25(\mathrm{OH})$ $\mathrm{D}$ plasma levels until reaching a plateau at 15 minutes. ${ }^{52}$ This has prompted the recommendation that the population should be exposed to sunlight for 15 minutes at least 3 times a week to cover VD requirements; however, similar studies are required in children and adolescents to validate this suggestion. In case of no sun exposure (e.g., few activities outdoors, weather conditions, clothing or seasonality), intake becomes the main source of VD. Given that few foods contain enough VD to cover vitamin requirements (Table 2 ) and that food vitamin contents vary depending on cooking methods (e.g., fried fish loses 50\% of VD), ${ }^{53}$ strategies such as fortified food consumption and the administration of $400 \mathrm{IU} /$ day during the first year of life have proven to be costeffective. ${ }^{15}$ Decades ago, oral doses of $600000 \mathrm{IU}$ were used worldwide to prevent VDD. However, subsequent studies found a higher probable effect on calcium metabolism, height involvement, and increased blood pressure. ${ }^{54}$ Subsequent studies have found that a dose between 100000 and $150000 \mathrm{IU}$ is enough to prevent VDD without known adverse effects. ${ }^{55}$ Table 3 includes some 
recommendations to prevent VDD in the pediatric population.

\section{Vitamin D deficiency management}

The evidence suggests that VD supplementation in clinical disorders at risk for VDD mentioned in this review to maintain $25(\mathrm{OH}) \mathrm{D}$ serum levels $>75 \mathrm{nmol} / \mathrm{L}$, the current cut-off point for sufficient levels, with potential modifications (Table 1). In most cases, VD3 doses between 400 and 1000 IU may be enough to maintain these values; however, if that is not the case, the dose should be adjusted whenever possible and 25(OH)D levels should be checked until reaching optimal levels. It has been suggested that children with $25(\mathrm{OH})$ D levels $<25 \mathrm{nmol} / \mathrm{L}$ should be referred to a specialized team for their assessment and management.

\section{CONCLUSIONS}

Available studies suggest that VD deficiency and insufficiency in the pediatric population is high. Several body functions may be affected by VD deficiency: bone, glucose, and acute immune metabolism, autoimmunity, etc.;
VD nuclear receptors may also be involved. Certain clinical disorders associated with VDD include obesity, prematurity, breastfeeding, intestinal malabsorption syndromes, and use of anticonvulsant agents, together with lifestyle conditions, body-covering clothing, living at extreme latitudes, low consumption of food sources, and little exposure to the sun.

More and more clinical disorders are now associated with VDD, so future studies are required to clarify $\mathrm{VD}^{\prime}$ s role in non-bone parameters in children and adolescents. The recommendation is to prevent and detect VDD in an early manner in the case of risk conditions and to maintain 25(OH)D serum levels $>75 \mathrm{nmol} / \mathrm{L}$.

\section{Homage}

This manuscript is published in memory of Carlos Castillo-Durán, M.D. ${ }^{+}$

\section{REFERENCES}

1. MaestroB,MoleroS, BajoS, etal. Transcriptional activation of the human insulin receptor gene by 1,25-dihydroxyvitamin D(3). Cell Biochem Funct 2002;20(3):227-32.

2. Carlberg C, Molnár F. Vitamin D receptor signaling and its therapeutic implications: Genome-wide and structural view. Can J Physiol Pharmacol 2015;93(5):311-8.

TABLE 2. Selected food contents of vitamin D

\begin{tabular}{|c|c|c|c|c|c|}
\hline Food $^{*}$ & $\begin{array}{c}\text { Content } \\
(\mathrm{IU} / \mathbf{1 0 0} \mathrm{g} \text { or } \mathrm{mL}) \\
\end{array}$ & $\begin{array}{l}\text { Serving measured } \\
\text { at home (g or } \mathrm{mL})\end{array}$ & $\begin{array}{c}\text { Content } \\
\text { (IU/serving) }\end{array}$ & $\begin{array}{c}\% \text { of adequacy for } \\
\leq 1 \text { year old ( } 400 \text { IU) } \\
\end{array}$ & $\begin{array}{c}\% \text { of adequacy for } \\
>1 \text { year old ( } 600 \mathrm{IU}) \\
\end{array}$ \\
\hline Salmon & 522 & Fillet (124 g) & 647 & 161.8 & 107.8 \\
\hline Horse mackerel & 292 & $3 \mathrm{oz}$ fillet (85 g) & 248 & 62 & 41.3 \\
\hline Tuna & 82 & $3 \mathrm{oz}$ fillet $(85 \mathrm{~g})$ & 70 & 17.5 & 11.7 \\
\hline Liver & 49 & Slice $(68 \mathrm{~g})$ & 33 & 8.3 & 5.5 \\
\hline Cheese (cheddar-like) & 24 & $1 \mathrm{oz}$ slice $(28 \mathrm{~g})$ & 7 & 2 & 1.2 \\
\hline Egg (yolk) & 530 & Unit (17 g) & 37 & 9.3 & 6.2 \\
\hline Mushrooms & 18 & Unit (19 g) & 3 & 1 & 0.5 \\
\hline Milk (fortified) & 49 & Cup (250 mL) & 120 & 30 & 20 \\
\hline
\end{tabular}

* Data from the United States Department of Agriculture (USDA) per $100 \mathrm{~g}$ or $\mathrm{mL}$ and per serving.

$\mathrm{IU}=$ international units $=0.025 \mu \mathrm{g}$. Adequate percentage of vitamin $\mathrm{D}$ for children $\leq 12$ months old, adults $>71$ years old and other groups according to the American Institute of Medicine: vitamin D requirements for term infants up to 12 months old are $400 \mathrm{IU}$, for adults older than 71 years, $800 \mathrm{IU}$, and for other groups, $600 \mathrm{IU} .^{57}$

TABLE 3. Vitamin D deficiency prevention in children and adolescents

The following recommendations have been made to prevent vitamin $\mathrm{D}$ deficiency in the pediatric population:

- Adequate sun exposure to the face, hands or legs (at least 3 times a week for 15 minutes).

- In extreme latitudes and during the winter, ensure an adequate consumption of food sources (Table 1).

- For infants, administer VD3 at 400 IU/day until 1 year old -due to the low VD content in breast milk, 22 IU/L (15-50 IU/L)_53 and in extreme latitudes, analyze the possibility of a higher dose and extend it to other pediatric age groups. Consider the possibility of substituting daily doses with high single doses (100 $000 \mathrm{IU}$ of VD) 2-3 times a year in case of problems with administration throughout the year. ${ }^{58}$

- Prevent overweight and obesity.

- Assess VD nutritional status in clinical diseases at risk for deficiency and administer according to recommendations (Table 1). 
3. Autier P, Boniol M, Pizot C, et al. Vitamin D status and ill health: a systematic review. Lancet Diabetes Endocrinol 2014;2(1):76-89.

4. Elder CJ, Bishop NJ. Rickets. Lancet 2014;383(9929): 166576.

5. Society for Adolescent Health and Medicine. Recommended vitamin D intake and management of low vitamin D status in adolescents: a position statement of the society for adolescent health and medicine. J Adolesc Health 2013;52(6):801-3.

6. Lindqvist PG, Epstein E, Nielsen K, et al. Avoidance of sun exposure as a risk factor for major causes of death: a competing risk analysis of the Melanoma in Southern Sweden cohort. J Intern Med 2016;280(4):375-87.

7. Hilger J, Friedel A, Herr R, et al. A systematic review of vitamin $\mathrm{D}$ status in populations worldwide. $\mathrm{Br} \mathrm{J} \mathrm{Nutr}$ 2014;111(1):23-45.

8. Brito $\mathrm{A}$, Cori $\mathrm{H}$, Olivares $\mathrm{M}$, et al. Less than adequate vitamin D status and intake in Latin America and the Caribbean: a problem of unknown magnitude. Food Nutr Bull 2013;34(1):52-64.

9. Durán P, Mangialavori G, Biglieri A, et al. Estudio descriptivo de la situación nutricional en niños de 6-72 meses de la República Argentina. Resultados de la Encuesta Nacional de Nutrición y Salud (ENNyS). Arch Argent Pediatr 2009;107(5):397-404.

10. Le Roy C, Reyes M, González JM, et al. Estado nutricional de vitamina $D$ en pre escolares chilenos de zonas australes. Rev Med Chil 2013;141(4):435-41.

11. Monangi N, Slaughter JL, Dawodu A, et al. Vitamin D status of early preterm infants and the effects of vitamin D intake during hospital stay. Arch Dis Child Fetal Neonatal Ed 2014;99(2):F166-8.

12. Fort $\mathrm{P}$, Salas A, Nicola $\mathrm{T}$, et al. A Comparison of 3 Vitamin D Dosing Regimens in Extremely Preterm Infants: A Randomized Controlled Trial. J Pediatr 2016;174:132-8.

13. Braegger C, Campoy C, Colomb V, et al. Vitamin D in the healthy European paediatric population. J Pediatr Gastroenterol Nutr 2013;56(6):692-701.

14. Cediel G, Corvalán C, Aguirre C, et al. Serum 25-Hydroxyvitamin D associated with indicators of body fat and insulin resistance in prepubertal Chilean children. Int J Obes (Lond) 2016;40(1):147-52.

15. CedielG, Corvalán C, López de RomañaD, etal.Prepubertal Adiposity, Vitamin D Status, and Insulin Resistance. Pediatrics 2016;138(1):e20160076.

16. Wortsman J, Matsuoka LY, Chen TC, et al. Decreased bioavailability of vitamin D in obesity. Am J Clin Nutr 2000;72(3):690-3.

17. Brinkmann $K$, Le Roy C, Iñiguez $G$, et al. Deficiencia severa de vitamina D en niños de Punta Arenas, Chile: influencia de estado nutricional en la respuesta a suplementación. Rev Chil Pediatr 2015;86(3):182-8.

18. Płudowski P, Karczmarewicz E, Bayer M, et al. Practical guidelines for the supplementation of vitamin $\mathrm{D}$ and the treatment of deficits in Central Europe-recommended vitamin $\mathrm{D}$ intakes in the general population and groups at risk of vitamin D deficiency. Endokrynol Pol 2013; 64(4):319-27.

19. Ding C, Wilding JPH, Bing C. 1,25-dihydroxyvitamin D3 protects against macrophage-induced activation of $N F \kappa B$ and MAPK signalling and chemokine release in human adipocytes. PLoS One 2013;8(4):e61707.

20. Belenchia AM, Tosh AK, Hillman LS, et al. Correcting vitamin $\mathrm{D}$ insufficiency improves insulin sensitivity in obese adolescents: a randomized controlled trial. Am JClin Nutr 2013;97(4):774-81.

21. Vitamin D supplement in early childhood and risk for Type
I (insulin-dependent) diabetes mellitus. The EURODIAB Substudy 2 Study Group. Diabetologia 1999;42(1):51-4.

22. Hyppönen E, Läärä E, Reunanen A, et al. Intake of vitamin $\mathrm{D}$ and risk of type 1 diabetes: a birth-cohort study. Lancet 2001;358(9292):1500-3.

23. Mathieu C, Badenhoop K. Vitamin D and type 1 diabetes mellitus: state of the art. Trends Endocrinol Metab 2005;16(6):261-6.

24. Mohr SB, Garland CF, Gorham ED, et al. The association between ultraviolet $\mathrm{B}$ irradiance, vitamin $\mathrm{D}$ status and incidence rates of type 1 diabetes in 51 regions worldwide. Diabetologia 2008;51(8):1391-8.

25. Liu C, Lu M, Xia X, et al. Correlation of serum vitamin D level with type 1 diabetes mellitus in children: a metaanalysis. Nutr Hosp 2015;32(4):1591-4.

26. Ginanjar E, Sumariyono, Setiati S, et al. Vitamin D and autoimmune disease. Acta Med Indones 2007;39(3):133-41.

27. Reis JP, von Mühlen D, Miller ER, et al. Vitamin D status and cardiometabolic risk factors in the United States adolescent population. Pediatrics 2009;124(3):e371-9.

28. Hirschler V, Maccallini G, Sanchez M, etal. Improvement of Apolipoprotein B in Argentine Indigenous School Children after Vitamin DSupplementation. Cardiovasc Hematol Agents Med Chem 2015;13(2):137-45.

29. Hirschler V, Molinari C, Maccallini G, et al. Status of Dyslipidemia in Vitamin D Supplemented Argentinean Indigenous Children Versus A Non-supplemented Mixed Population Group. Cardiovasc Hematol Agents Med Chem 2015;13(2):129-36.

30. HirschlerV,MaccalliniG,TamboreneaMI,etal.Improvement in lipid profile after vitamin D supplementation in indigenous Argentine school children. Cardiovasc Hematol Agents Med Chem 2014;12(1):42-9.

31. PyrżakB,Witkowska-SędekE,Krajewska M, etal. Metabolic and immunological consequences of vitamin D deficiency in obese children. Adv Exp Med Biol 2015;840:13-9.

32. Dror Y, Giveon SM, Hoshen M, et al. Vitamin D levels for preventing acute coronary syndrome and mortality: evidence of a nonlinear association. J Clin Endocrinol Metab 2013;98(5):2160-7.

33. Al-Shoumer KA, Al-Essa TM. Is there a relationship between vitamin D with insulin resistance and diabetes mellitus? World J Diabetes 2015;6(8):1057-64.

34. Margulies SL, Kurian D, Elliott MS, et al. Vitamin D deficiency in patients with intestinal malabsorption syndromes--think in and outside the gut. J Dig Dis 2015;16(11):617-33.

35. Norton L, PageS, Sheehan M, etal. Prevalence of inadequate vitamin D status and associated factors in children with cystic fibrosis. Nutr Clin Pract 2015;30(1):111-6.

36. Simoneau T, Bazzaz O, Sawicki GS, et al. Vitamin D Status in Children with Cystic Fibrosis. Associations with Inflammation and Bacterial Colonization. Ann Am Thorac Soc 2014;11(2):205-10.

37. Tangpricha V, Kelly A, Stephenson A, et al. An update on the screening, diagnosis, management, and treatment of vitamin D deficiency in individuals with cystic fibrosis: evidence-based recommendations from the Cystic Fibrosis Foundation. J Clin Endocrinol Metab 2012;97(4):1082-93.

38. Caruso R, Pallone F, Stasi E, et al. Appropriate nutrient supplementation in celiac disease. Ann Med 2013;45(8): 522-31.

39. Tanpowpong P, Camargo CA. Early-life vitamin D deficiency and childhood-onset coeliac disease. Public Health Nutr 2014;17(4):823-6.

40. Capriles VD, Martini LA, Arêas JAG. Metabolic osteopathy in celiac disease: importance of a gluten-free diet. Nutr Rev 2009;67(10):599-606. 
41. Le Roy OC, Rebollo GM, Moraga FM, et al. Nutrición del Niño con Enfermedades Neurológicas Prevalentes. Rev Chil Pediatr 2010;81(2):103-13.

42. Belderbos ME, Houben ML, Wilbrink B, et al. Cord blood vitamin D deficiency is associated with respiratory syncytial virus bronchiolitis. Pediatrics 2011;127(6):e1513-20.

43. Łuczyńska A, Logan C, Nieters A, et al. Cord blood 25(OH) $D$ levels and the subsequent risk of lower respiratory tract infections in early childhood: the Ulm birth cohort. Eur J Epidemiol 2014;29(8):585-94.

44. Esposito S, Lelii M. Vitamin D and respiratory tract infections in childhood. BMC Infect Dis 2015;15:487.

45. Urashima M, Segawa T, Okazaki M, et al. Randomized trial of vitamin D supplementation to prevent seasonal influenza A in schoolchildren. Am J Clin Nutr 2010;91(5):1255-60.

46. Tang JY, Epstein EH. Vitamin D and skin cancer. In: Feldman j, Pike W, Adams J. Vitamin D. 3rd ed. San Diego, CA:Elsevier; 2011:1751-62. doi:10.1016/B978-0-12-3819789.10089-7.

47. Xiao L, Xing C, Yang Z, et al. Vitamin D supplementation for the prevention of childhood acute respiratory infections: a systematic review of randomised controlled trials. $\mathrm{Br} \mathrm{J}$ Nutr 2015;114(7):1026-34.

48. Einisman H, Reyes ML, Angulo J, al. Vitamin D levels and vitaminDreceptorgenepolymorphismsinasthmaticchildren: a case-control study. Pediatr Allergy Immunol 2015;26(6):545-50.

49. Kerley CP, Hutchinson K, Cormican L, et al. Vitamin D3 for uncontrolled childhood asthma: A pilot study. Pediatr Allergy Immunol 2016;27(4):404-12. doi:10.

50. Villamor E, Marin C, Mora-Plazas M, et al. Vitamin D deficiency and age at menarche: a prospective study. $A m$
Clin Nutr 2011;94(4):1020-5

51. Kao KT, Abidi N, Ranasinha S, et al. Low vitamin D is associated with hypertension in paediatric obesity. J Paediatr Child Health 2015;51(12):1207-13.

52. Davie M, Lawson DE. Assessment of plasma 25-hydroxyvitamin D response to ultraviolet irradiation over a controlled area in young and elderly subjects. Clin Sci (Lond) 1980;58(3):235-42.

53. Misra M, Pacaud D, Petryk A, et al. Vitamin D deficiency in children and its management: review of current knowledge and recommendations. Pediatrics 2008;122(2):398-417.

54. Holmlund-Suila E, Viljakainen H, Hytinantti T, et al. Highdose vitamin d intervention in infants--effects on vitamin D status, calcium homeostasis, and bone strength. J Clin Endocrinol Metab 2012;97(11):4139-47.

55. Oliveri B, Cassinelli H, Mautalen C, et al. Vitamin D prophylaxis in children with a single dose of $150000 \mathrm{IU}$ of vitamin D. Eur J Clin Nutr 1996;50(12):807-10.

56. Tachimoto $\mathrm{H}$, Mezawa $\mathrm{H}$, Segawa $\mathrm{T}$, et al. Improved control of childhood asthma with low-dose, short-term vitamin D supplementation: a randomized, double-blind, placebocontrolled trial. Allergy 2016;71(7):1001-9.

57. Boucher BJ. The 2010 recommendations of the American Institute of Medicine for daily intakes of vitamin D. Public Health Nutr 2011;14(4):740.

58. Tau C, Ciriani V, Scaiola E, et al. Twice single doses of $100,000 \mathrm{IU}$ of vitamin D in winter is adequate and safe for prevention of vitamin D deficiency in healthy children from Ushuaia, Tierra Del Fuego, Argentina. J Steroid Biochem Mol Biol 2007;103(3-5):651-4. 